\title{
Assessment of labor potential on the regional level by the index method
}

\author{
Marina Simonova ${ }^{1, *}$, Sergei Kolesnikov ${ }^{2}$, and Tatiana Karakova ${ }^{2}$ \\ ${ }^{1}$ Samara State University of Economics, Sovetskoi Armii Street, 141, 443090, Samara, Russia \\ ${ }^{2}$ Samara State Technical University, Institute of Architecture and Civil Engineering, \\ Molodogvardeyskaya str. 194, 443001 Samara, Russia
}

\begin{abstract}
Analysis and tendencies in labor potential development are part of a complex socio-economic system. This system as well as its state is of great importance for justification of investments and further vectors of development. At present, however, there is no generally accepted methodology for labor potential assessment. The authors introduce the index method to assess basic characteristics of labor potential taking the Samara region as an example. The research is based on the calculations labor potential indices in the Samara region. The authors detect changes in labor potential structure which are due to the growth of indices of education, labor efficiency and scientific research with some decrease in the index of demographic performance. The obtained results serve as a basis for determining the possibilities of area development and help to see the logic of advanced labor potential formation.
\end{abstract}

\section{Introduction}

Economic development of a country is determined, first of all, by those people who live and work on its territory. The level and quality of life, well-being and industrial growth mostly depend on population workability. There is a need for a progressive increase in the work potential and a constant search of reserves for labor potential formation to ensure the sustainable development of key sectors of the economy. All these reasons ensure the relevance of this study. The assessment of labor potential characteristics is of special importance. The central issues here are education and skills of workers. There is also a need to develop conceptual approaches that implement opportunities and prospects of labor potential development in the context of key measures of social and economic policy of the state [2].

Different regions of the Russian Federation have different structure, level of economic development, level and quality of life, which create conditions for regional differentiation of labor resources and hinder regional development. The lack of opportunities for labor potential formation and realization can serve as a threat to the effective development of the region's economy and strengthen intraregional inequalities caused by different natural conditions and historical background. There exist significant regional and industry-specific differences in

\footnotetext{
*Corresponding author: m.simonova@mail.ru
} 
quantitative and qualitative parameters of labor potential which can hinder complex development, create economic disproportion in the system of economic interaction. All this prevents effective use of available natural resources. The increasing demand of the economy in innovative development and labor potential realization stimulate research studies which aim at changing labor potential structure and reveal tendencies of its development [3]. Despite the active development and implementation of target state and regional labor management programmes, there is often no comprehensive approach to different aspects of labor potential formation and use. In addition, there is no correlation between education results and earned income, there is no long-term policy of planning the needs of the economy in qualified personnel, there is a decline in the quality of labor potential in certain regions. The solution of these problems is hampered by the lack of consistent approach to methods of labor potential assessment, incoherence of goals and tasks of advanced labor potential formation. The development of approaches to labor potential assessment requires scientific rationale and methodical support, which confirms the relevance of the selected research topic.

\section{Assessment of labor potential on the regional level}

The purpose of the research is to revel tendencies in labor potential development. The study is based on the analysis of the existing regional level. Calculations of index potentials are taken as an example. To achieve the goal of the study the researchers plan to fulfil the following tasks:

- to examine the structure of labor potential in the Samara region and to implement the index approach for labor potential assessment;

- to define quantitative characteristics of labor potential in the Samara region on the basis of demographic, migration, labor, educational and structural data;

- to assess the current situation on the basis of the calculation of index potentials and characteristics of labor potential in the Samara region;

- to see the logic of advanced labor potential formation for determining directions of labor potential development.

The analysis and research of demographic, migration, structural indicators of labor potential in accordance with statistics data and labor market of the Samara region studies served as the research base for the present study. To assess the current state of labor potential at the regional level, the authors took the Samara region as one of industrially developed regions of the Russian Federation, which has significant natural and human resources. In the beginning of 2017, the Samara region was ahead of other regions both in the Volga Federal District and in the Russian Federation upon employment and economic activity indications. Its unemployment rates were among the lowest in the whole country [4]. However, there is a shortage of qualified personnel in the region, which particularly affects the priority sectors of the economy. It is of a scientific and practical interest to reveal tendencies in the structure of labor potential to identify development opportunities.

Tendencies of economic development in Russia and its regions are greatly determined by quantity and quality of human resources which can be used in certain territories [5]. The reason for that is the transition of the economy to the industrial phase, the increase of the influence of information technologies on all spheres of life, production intellectualization, the dynamics of which depends on the quality of the employed workforce [6]. It is through the innovative qualities of the workforce that you can increase the competitiveness of all areas of the economy and create breakthrough technologies. Education system, which is the basis for the formation and development of labor force quality characteristics, plays a decisive role here. Qualitative and quantitative characteristics of labor resources are closely related. Quantitative indicators serve as a basis for planning the structure of the workforce quality and for all directions and levels of economic activities staffing [8]. 
One of the important characteristics of quantitative parameters is the age structure of the labor force. It has a tendency to reduce the proportion of young people and to increase the number of older people, which leads to an increase in the economic burden on economically active population, risks in social security, distortion in employment (see Fig. 1).

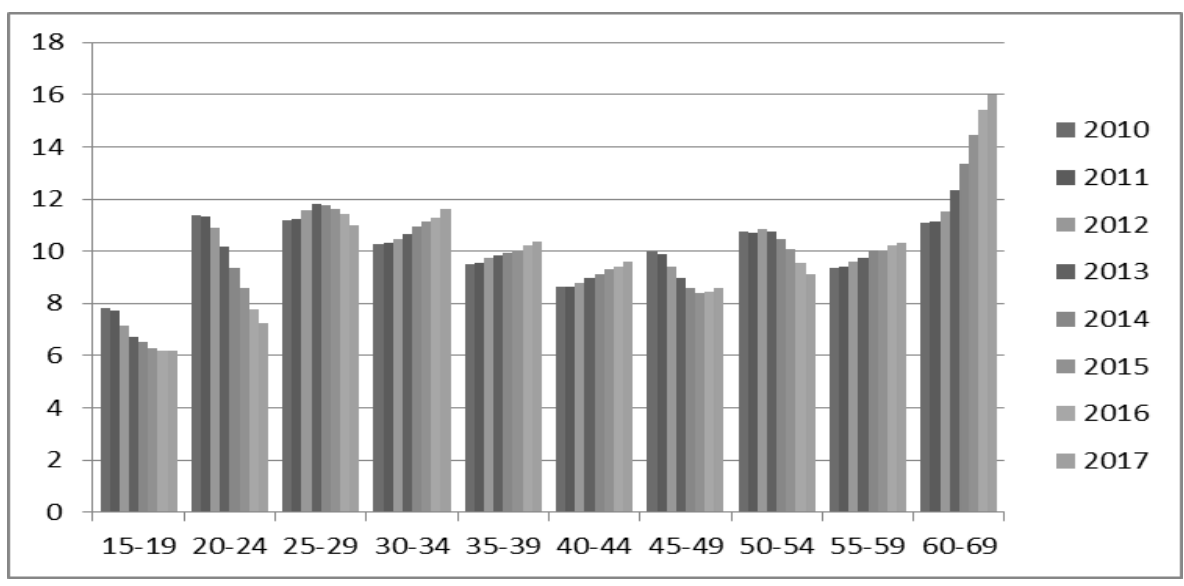

Fig. 1. Distribution of the number of employed in the Russian Federation according to age groups (calculated on the basis of Samarastat data [9])

The most significant indicator of the dynamics of labor quality is the level of education of the population in the region. Vocational education in the modern world economy plays the role of the catalyst for many socio-economic processes.

It is a significant social institution, shaping the environment and determining the ways of society development $[10,11]$.

Graduates educated in the Samara region work all over Russia and abroad. The educational system of the Volga region attracts many people from different cities and villages of Russia and from abroad. Assessment of educational level of the population and the received education structure allow to carry out qualitative analysis of labor resources and to estimate prospects of development.

Labor migration has an increasing impact on the state of labor potential [12]. The influx or outflow of labor migrants can have a significant impact on the state of labor potential. Regions are interested in the influx of skilled labor, but there should be favorable conditions created in the region to attract skilled labor force. Effective workplaces, intensive technologies, development of automation and robotic, developed education system are critical elements of labor potential formation.

One of the most reliable methods of assessing the real state of labor potential is the factor analysis of statistical indicators with the highest degree of certainty. Data analysis can be carried out by using several calculation groups: they are natural, cost and index approaches. Let's start with the index method, which allows to describe the main characteristics of labor potential. The main characteristics of labor potential and approaches to their calculation are shown in Table 1.

To calculate the Labor potential index (LPI), let us use the following formula:

$$
L P I=\frac{I_{d p}+I_{e d}+I_{n}+I_{l m}+I_{l e}}{\sum_{i=1}^{5} k_{i}}
$$


Table 1. Indicators (factors) for labor potential assessment

\begin{tabular}{|c|c|c|}
\hline Index & Index characteristics & Calculation formula \\
\hline \multirow[t]{2}{*}{$\begin{array}{l}\mathrm{I}_{\mathrm{dp}}-\text { index of demographic } \\
\text { productivity }\end{array}$} & \multirow[t]{2}{*}{$\begin{array}{l}\text { It characterizes the } \\
\text { reproduction of labor } \\
\text { resources, takes into } \\
\text { account the influence of } \\
\text { most productive age of } \\
\text { economic active } \\
\text { population }\end{array}$} & $\begin{array}{l}\qquad I_{d p}=\frac{P_{(20-44)}}{P_{n}} \mathrm{X} \frac{1}{p_{d p}} \\
P_{(20-44)-\text { number of employed population aged } 20-44 \text { years, }} \\
\text { thousand people; } P_{n}-\text { number of economic active } \\
\text { population, thousand people; } p_{d p}-\text { index potential of } \\
\text { demographic reproduction. }\end{array}$ \\
\hline & & $\begin{array}{l}\qquad \mathrm{p}_{\mathrm{dp}}=\frac{1}{\mathrm{n}} \sum_{\mathrm{i}}^{\mathrm{n}}\left[\frac{\mathrm{P}_{(20-44)}}{\mathrm{P}_{\mathrm{n}}}\right] \mathrm{i} \\
\mathrm{i}-\text { number of the year in the period under investigation; } \mathrm{n}- \\
\text { number of years the period under investigation }\end{array}$ \\
\hline \multirow[t]{2}{*}{$\begin{array}{l}\mathrm{I}_{\mathrm{ed}}-\text { human } \\
\text { education Index }\end{array}$} & \multirow[t]{2}{*}{$\begin{array}{l}\text { It takes into account labor } \\
\text { resources qualitative } \\
\text { characteristics }\end{array}$} & $\begin{array}{l}\qquad I_{e d}=\frac{G_{I-I I}+G_{I I I-I V}}{P_{15-24}} \times \frac{1}{p_{e d}} \\
\mathrm{G}_{\mathrm{I}-\mathrm{II}}-\text { number of graduates of educational institutions (I-II } \\
\text { levels of accreditation, thous. people); } \mathrm{G}_{\mathrm{III}-\mathrm{IV}}-\text {-number of } \\
\text { graduates (III-IV accreditation levels, thous. people); } \mathrm{N}_{15-24} \\
\text { - number of people aged } 15-24 \text { years, thous. people; } \mathrm{p}_{\text {ed }} \\
\text { index potential of education }\end{array}$ \\
\hline & & $\mathrm{p}_{e d}=\frac{1}{n} \sum_{i}^{n}\left[\frac{G_{I-I I}+G_{I I I-I V}}{P_{15-24}}\right] \mathrm{i}$ \\
\hline \multirow[t]{2}{*}{$\begin{array}{l}\mathrm{I}_{\mathrm{r}}-\text { index of the scale of } \\
\text { research work }\end{array}$} & \multirow[t]{2}{*}{$\begin{array}{l}\text { It shows the scientific and } \\
\text { technical component of } \\
\text { the work activity results. }\end{array}$} & $\begin{array}{l}\qquad I_{r}=\frac{F R+A R}{S W} \times \frac{1}{\mathrm{p}_{s}} \\
\mathrm{FR}-\text { scope of fundamental scientific researches, } \mathrm{mln} \text {. } \\
\text { rubles; } \mathrm{AR}-\text { scope of applied scientific research, } \mathrm{mln} \text {. } \\
\text { rubles; } \mathrm{SW}-\text { amount of scientific research works, } \mathrm{mln} \text {. } \\
\text { rubles; } \mathrm{p}_{\mathrm{s}}-\text { index potential of qualification }\end{array}$ \\
\hline & & $\mathrm{p}_{s}=\frac{1}{n} \sum_{i}^{n}\left[\frac{F R+A R}{S W}\right] i$ \\
\hline \multirow[t]{2}{*}{$\mathrm{I}_{\mathrm{lm}}$ - Labor migration index } & \multirow[t]{2}{*}{$\begin{array}{l}\text { It allows to assess changes } \\
\text { in labor potential caused } \\
\text { by migration of population }\end{array}$} & $\begin{array}{l}\qquad I_{l m}=\frac{P_{\mathrm{w}}+P_{o}}{M_{\mathrm{w}}+M_{o}} \times \frac{1}{\mathrm{p}_{l m}} \\
\mathrm{P}_{\mathrm{w}}-\text { the number of migrants moving within the region, } \\
\text { people; } \mathrm{P}_{\mathrm{o}}-\text { the number of migrants coming to the region } \\
\text { from outside, people; } \mathrm{M}_{\mathrm{w}}-\text { the number of departing } \\
\text { migrants within the region, people; } \mathrm{M}_{\mathrm{o}}-\text { the number of } \\
\text { migrants leaving the region, people; } \mathrm{p}_{\mathrm{lm}}-\text { index potential } \\
\text { of labor migration }\end{array}$ \\
\hline & & $\mathrm{p}_{l m}=\frac{1}{n} \sum_{i}^{n}\left[\frac{P_{w}+P_{o}}{M_{w}+M_{o}}\right] i$ \\
\hline \multirow[t]{2}{*}{$\mathrm{I}_{\mathrm{le}}-$ Labor efficiency index } & \multirow{2}{*}{$\begin{array}{l}\text { It allows to estimate the } \\
\text { volume of the gross } \\
\text { regional product to the } \\
\text { income of population who } \\
\text { have produced this GRP. } \\
\text { It is accepted as an axiom } \\
\text { of the dependence } \\
\text { between labor volumes } \\
\text { and income of the } \\
\text { population }\end{array}$} & $\begin{array}{l}\qquad I_{i e}=\frac{G R P}{G I} \times \frac{1}{\mathrm{p}_{e}} \\
\text { GRP }- \text { Gross regional product, mln. rubles; GI }- \text { Gross } \\
\text { income of the population, mln. rubles; } \mathrm{p}_{\mathrm{e}}-\text { index potential } \\
\text { of labor efficiency }\end{array}$ \\
\hline & & $\mathrm{p}_{e}=\frac{1}{n} \sum_{i}^{n}\left[\frac{G R P}{G I}\right] i$ \\
\hline
\end{tabular}

The calculation of indices in the Samara region was made on the basis of statistics in the Samara region for 2015 and 2016 (see Table 2). 
Table 2. Results of calculation of labor potential indices of Samara region for 2015 and 2016

\begin{tabular}{|l|l|l|l|l|l|l|}
\hline Index & \multicolumn{2}{|l|}{$\begin{array}{l}\text { The value of the first part } \\
\text { of the formula (N) }\end{array}$} & \multicolumn{2}{l|}{$\begin{array}{l}\text { Index } \\
\text { potentials }\left(\mathrm{p}_{j}\right)\end{array}$} & \multicolumn{2}{l|}{ Weighted index $I_{j}=N * \frac{1}{\mathrm{p}_{j}} \quad$ (16) } \\
\hline & 2015 & 2016 & 2015 & 2016 & 2015 & 2016 \\
\hline$I_{\text {дП }}$ & 0.653 & 0.605 & 0.63 & 0.63 & 1.04 & 0.96 \\
\hline$I_{\mathrm{O}}$ & 0.182 & 0.218 & 0.2 & 0.2 & 0.91 & 1.09 \\
\hline$I_{\mathrm{H}}$ & 0.115 & 0.138 & 0.13 & 0.13 & 0.88 & 1.06 \\
\hline$I_{\text {тм }}$ & 0.971 & 1.028 & 0.99 & 0.99 & 0.98 & 1.04 \\
\hline$I_{\text {э }}$ & 1.141 & 1.271 & 1.21 & 1.21 & 0.94 & 1.06 \\
\hline LPI & & & & 0.95 & 1.042 \\
\hline
\end{tabular}

Calculation of indices of labor potential for 2015-2016 and index potentials make it possible to determine the dynamics of indices constituting the characteristic of the labor potential and to identify indices for which there is a growth or a fall. The results of data analysis presented in Table 1 show that the components of the labor potential in the Samara region have changed unevenly and in 2016 there was an increase in all index values, except for the index of demographic productivity. It could be a result of consequences of the demographic pitfall in the 1990s. The calculations can also be used to compare the indices of labor potential here with other regions and in the Russian Federation in general. For example, the education index of the Samara region is a positive trend, it is constantly increasing and holds the $9^{\text {th }}$ position in the country, which is good enough considering the number of regions [13]. In general, due to the growth of economic indicators, the labor potential index in 2016 was 1.042 , that is, the labor potential of the Samara region grew by $4.2 \%$. However, the calculation of labor potential has limited characteristics and does not allow to fully assess the quality of labor potential in many qualitative parameters as there isn't enough data. That is why additional studies with the use of on-site monitoring of personnel at enterprises are required and monitoring of the quality of management decision regarding labor potential at the regional and federal levels seems also useful. At the same time, the calculations do not contain such important qualitative indicators of labor potential as health, cultural and moral levels, population social activity These indicators are represented in the statistical data, still they have a significant impact on the quality of labor potential. These parameters assessment can be done through expert assessments, representative surveys and indirect indicators. Nevertheless, this technique availability and ease of use can be highly appreciated because statistical data used in the calculations can be selected from available sources. This methodology allows to assess the labor potential of the region with a fairly high degree of objectivity, which is an essential requirement for public administration.

The formation of labor potential of the region is connected with the organization of complex interaction between different branches of power, business and education. This interaction is necessary to achieve a balance of quality of labor at all stages of management and production of consumer goods. The advanced labor potential, characterized by high quality of labor force, is required today by high-tech branches of economy. They need qualified labor force to achieve breakthrough results, allowing to make a complex technological breakthrough as it is at this level the global challenges facing the whole economy of the country can be faced [14]. The formation of advanced labor potential occurs in a certain sequence and under the influence of various objective and subjective factors (see Fig. 2). 


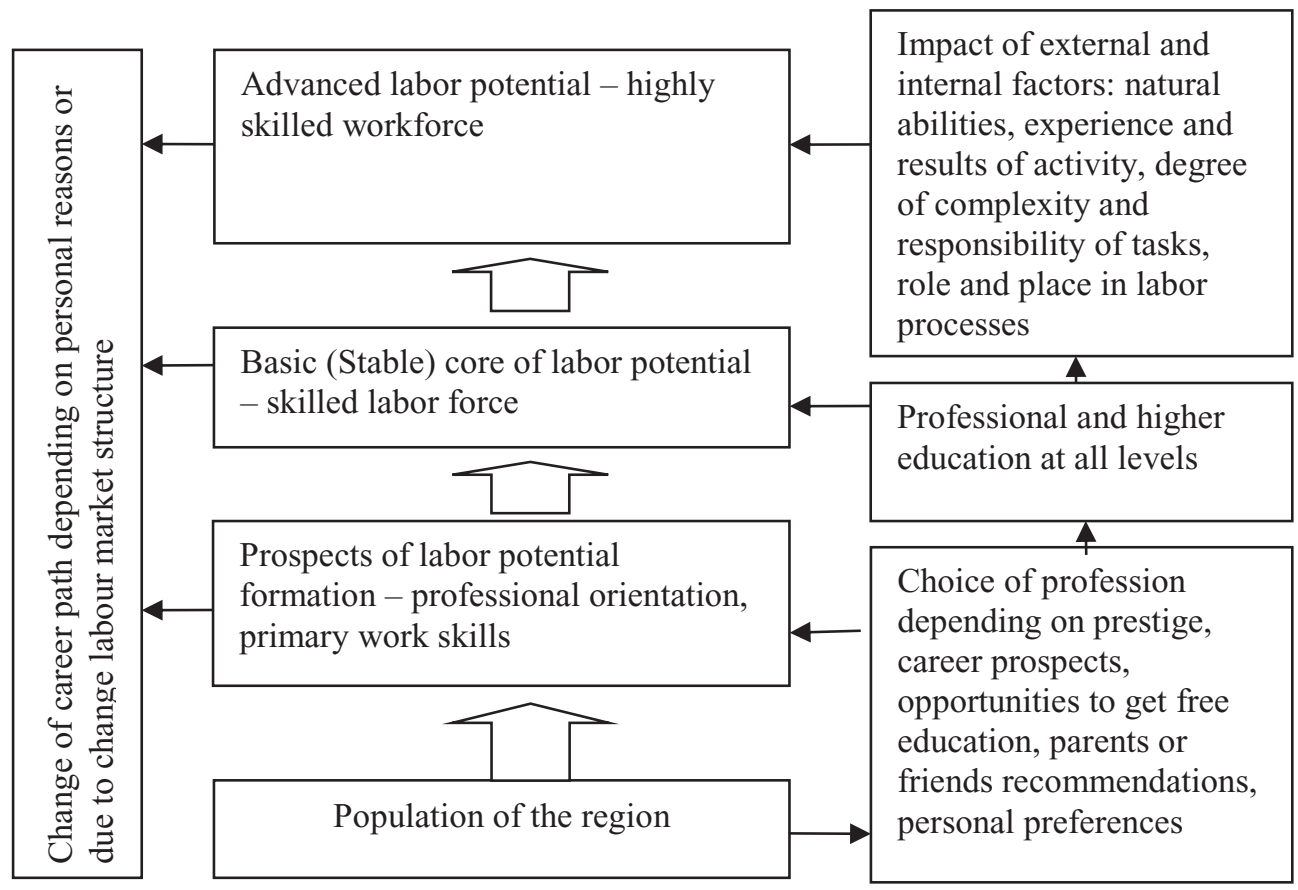

Figure 2. The logic of advanced labor potential formation

Natural abilities of a person, determined genetically, together with his living environment, a level of society development, both in technical-technological, and in social sphere, determine this person's choice of a profession and a career. In different periods of society development there is cyclical redistribution of labor potential into more effective spheres of economy, which makes a significant impact to the education system as far as labor force retraining is concerned [15]. This circumstance adds certain peculiarities to the process of professional education and influences skilled labor force and redistribution of labor potential.

\section{Conclusion}

The research demonstrates that existing tendencies of change in the structure of labor potential are caused mainly by a changing demographic situation. The authors based their study on the calculations of labor potential characteristics in the Samara region - a large industrial region of the Russian Federation with developed infrastructure - and found index potentials for the following significant labor potential characteristics: demographic productivity, education of labor resources, scale of research work, labor migration and labor efficiency. The analysis of labor potential in the Samara region, on the basis of characteristics assessment with the index method, showed a slight growth of indices of main indicators, except for the index of demographic productivity and revealed a change in its structure that had occurred in recent years. It means that there is some potential for more intensive growth in the workforce, which requires an advanced target programme to increase its rate of growth. At the same time, there is a risk of reducing labor potential through reduced demographic productivity, which must be taken into account in the draft programme. The research also helps recognize growth potential of labor force and suggests necessary measures to compensate for negative trends. The result obtained in the study is important for the development of the state policy of labor potential formation. To achieve this goal, the 
researchers have applied the logic of advanced labor potential formation, which can serve as a starting point for further studies.

It is also determined that the system of education, which forms the basis of labor quality and has a special influence on labor potential formation, creates additional opportunities for the development of the region's economy. On the basis of the index of labor resources education and its growth, it is shown that a proportion of population in the Samara region with higher and secondary vocational education is comparatively high. However, the rate of growth of labor force indices is negligible. It cannot satisfy the growing need of the region's economy for skilled labor. For a further research we suggest determining prospective needs for qualified labor force and calculating amount of labor potential. Such perspective results will be important for the formation of practice-oriented educational programs, for determination of the state funds for labor training, and for plans of professional retraining in conditions of enterprises restructuring.

Thus, there are real opportunities for increasing labor potential and its use in the Samara region for improving the quality of labor activity. Further measures in this direction require additional research. On the basis of such studies a unique, effective system of labor potential management of the region can be formed.

\section{References}

1. M. Nakajima, International Economic Review 53, 399-432 (2012)

2. S. Ellison, B. Allen. CSSE. 13, 1, pp 267-298 (2018)

3. Roszko-Wójtowicz, E., Bialek, J. Statistics in Transition, 18(1), 167-180 (2017)

4. Ministry of economic development, investments and trade of the Samara region: Samara region in figures http://economy.samregion.ru/activity/ekonomika/values_so/\#job (reference date: 20.03.2018)

5. M. Simonova, N. Shekhova, S. Kolesnikov. MATEC Web Conf., 86, (2016)

6. L. Connolly, A. Sheehan. Studies in Nonlinear Dynamics \& Econometrics, 22(1), (2018)

7. T. Sendlhofer, C. MyLernborg. Journal of Cleaner Production, 179, 1, 616-630 (2018)

8. N.Whelan, S. McGilloway, M.P. Murphy. Trials, 19, 1, 1 (2018)

9. Regional office of the Federal Service of State statistics in the Samara region [electronic resource]: http://samarastat.gks.ru (reference date: 01.04.2018)

10. M. Dale, McCartney, A. S. Tertiary Education and Management, (2018)

11. Tyurikov, A.G., Orehovskaya, N.A., Bolshunov, A.Y., Azizova, A.N. International Conference «IT\&QM\&IS», 696-698 (2017)

12. A. H. Akbari, A. Haider. Journal of International Migration and Integration. 19, 1, 129142 (2018)

13. D.I. Faizrakhmanov, L.R. Shagivaliev. Bulletin of the Kazan State Agrarian University, 11, 2, 108-111 (2016)

14. Garbuz, V., Topala, P. IOP Conference Series: Materials Science and Engineering, 227, 1 (2017)

15. J. Wayne. Labor 2 (1), 55-116 (2015) 